\title{
FIFTEENTH ANNUAL LIST OF PAPERS
}

\section{READ BEFORE THE AMERICAN MATHEMATICAL SOCIETY AND SUBSEQUENTLY PUBLISHED, INCLUDING REFERENCES TO THE PLACES OF THEIR PUBLICATION.}

Ames, L. D. Supplementary Communication on the Division of Space by a Closed Surface. Read Sept. 16, 1904. American Journal of Mathematics, vol. 27, No. 4, pp. 343-380 ; Oct., 1905.

Birkhoff, G. D. General Mean Value and Remainder Theorems with Applications to Mechanical Differentiation and Quadrature. Read Feb. 27, 1904. Transactions of the American Mathematical Society, vol. 7, No. 1, pp. 107-136 ; Jan., 1906.

BLIss, G. A. A Generalization of the Notion of Angle. Read Sept. 7, 1905. Transactions of the American Mathematical Society, vol. 7, No. 2, pp. 184196 ; Apr., 1906.

- A Proof of the Fundamental Theorem of Analysis Situs. Read Dec. 28, 1905. Bulletin of the American Mathematical Society, vol. 12, No. 7, pp. 336-341 ; Apr., 1906.

Burss, G. A. and Mason, Max. A Problem of the Calculus of Variations in which the Integrand is Discontinuous. Read Oct. 28, 1905. Transactions of the American Mathematical Society, vol. 7, No. 2, pp. 325-336; Apr., 1906.

Bolza, Oskar. A Fifth Necessary Condition for a Strong Extremum of the Integral

$$
\int_{x_{0}}^{x_{1}} F\left(x, y, y^{\prime}\right) d x
$$

Read Feb. 24, 1906. Transactions of the American Mathematical Socety, vol. 7, No. 2, pp. 314-324 ; Apr., 1906.

Bromwrch, T. J. I'A. The Classification of Quadrics. Read Sept. 17, 1904. Transactions of the American Mathematical Society, vol. 6, No. 3, pp. 275285 ; July, 1905.

Brows, E. W. On a General Method for Treating Transmitted Motions and its Application to Indirect Perturbations. Read Feb, 25, 1905. Transactions of the American Mathematical Society, vol. 6, No. 3, pp. 332-343; July, 1905.

Bussey, W. H. Galois Field Tables for $p^{n} \leqq 169$. Read Sept. 7, 1905. Bulletin of the American Mathematical Society, vol. 12, No. 1, pp. 22-38; Oct., 1905.

- See Veblen, Oswald.

Carstens, Mrss R. I. A Definition of Quaternions by Independent Postulates. Read Feb. 24, 1906. Bulletin of the American Mathematical Society, vol. 12 , No. 8, pp. 392-394; May, 1906. 
Carver, W. B. On the Cayley-Veronese Class of Configurations. Read Oct. 28, 1905. Transactions of the American Mathematical Society, vol. 6, No. 4, pp. 534-545 ; Oct., 1905.

CoBle, A. B. On the Relation between the Three-Parameter Groups of a Cubic Space Curve and a Quadric Surface. Read Dec. 29, 1904. Transactions of the American Mathematical Society, vol. 7, No. 1, pp. 1-20; Jan., 1906.

Curtiss, D. R. Sur la Théorie des Fonctions hypergéométriques. Read Sept. 16, 1904. Annales Scientifiques de l'Ecole Normale Supérieure, ser. 3, vol. 22, No. 3, pp. 121-143 ; Mar., 1906.

- Theorems Converse to Riemann's on Linear Differential Equations. Read Apr. 29, 1905. Transactions of the American Mathematical Society, vol. 7, No. 1, pp. 99-106 ; Jan., 1906.

On Certain Properties of Wronskians and Related Matrices. Read (Chicago) Apr. 14, 1906. Bulletin of the American Mathematical Society, vol. 12, No. 10, pp. 482-485; July, 1906.

Davis, E. W. The Elliptic Functions and the General Symmetric Group in Four Letters. Read (Chicago) Dec. 31, 1903. Nebraska University Studies, vol. 4, No. 3, pp. 231-247; July, 1904.

Drckson, L. E. Subgroups of Order a Power of $p$ in the General and Special $m$-ary Linear Homogeneous Groups in the $G F\left[p^{n}\right\rceil$. Read Sept. 16, 1904. American Journal of Mathematics, vol. 27, No. 3, pp. 280-302; July, 1905.

On Hypercomplex Number Systems. Read (Chicago) Apr. 22, 1905. Transactions of the American Mathematical Society, vol. 6, No. 3, pp. 344348 ; July, 1905.

On the Real Elements of Certain Classes of Geometrical Configurations. Read (Chicago) Apr. 22, 1905. Annals of Mathematics, ser. 2, vol. 6, No. 4, pp. 141-150; July, 1905.

On Finite Algebras. Read Sept. 8, 1905. Göttinger Nachrichten, 1905, No. 4, pp. 358-393.

- On the Quaternary Linear Homogeneous Groups Modulo $p$ of Order a Multiple of $p$. Read Sept. 8, 1905. American Journal of Mathematics, vol. 28, No. 1, pp. 1-16; Jan., 1906.

- Expressions for the Elements of a Determinant in Terms of the Minors of a Given Order. Generalization of a Theorem due to Studnička. Read (Chicago) Dec. 30, 1905. American Mathematical Monthly, vol. 12, No. 12, pp. 217-221 ; Dec., 1905.

- On Quadratic, Hermitian and Bilinear Forms. Read (Chicago) Dec. 30, 1905. Transactions of the American Mathematical Society, vol. 7, No. 2, pp. 275-292; Apr., 1906.

Dopd, E. L. On Iterated Limits of Multiple Sequences. Read Apr. 30, 1904. Mathematische Annalen, vol. 61, No. 1, pp. 95-108; Sept., 1905.

Eimsland, John. On a Certain System of Conjugate Lines on a Surface Connected with Euler's Transformation. Read Sept. 1, 1903. Transactions of the Americ in Mathematical Society, vol. 6, No. 4, pp. 450-471; Oct., 1905 .

Eisenhart, L. P. Surfaces of Constant Curvature and their Transformations. Read Apr. 29, 1905. Transactions of the American Mathematical Society, vol. 6, No. 4. pp. 472-485; Oct., 1905. 
Epsteen, Saul. Note on the Structure of Hypercomplex Number Systems. Read Sept. 7, 1905. Bulletin of the American Mathematical Society, vol. 12, No. 2, pp. 69-71; Nov., 1905.

Epsteen, Saul and Leonard, H. B. On the Definition of Reducible Hypercomplex Number Systems. Read (Chicago) Apr. 2, 1904. American Journal of Mathematics, vol. 27, No. 3, pp. 217-242 ; July, 1905.

Field, Peter. Quintic Curves for which $P=1$. Read Sept. 2, 1902. American Journal of Mathematics, vol. 27, No. 3, pp. 243-247; July, 1905.

- On the Form of a Plane Quintic Curve with Five Cusps. Read (Chicago) Apr. 11, 1903. Transactions of the American Mathematical Society, vol. 7, No. 1, pp. 2 i-32 ; Jan., 1906.

- Note on Certain Groups of Transformations of the Plane into Itself. Read Dec. 29, 1905. Bulletin of the American Mathematical Society, vol. 12, No. 5, pp. 234-236 ; Feb., 1906.

Fite, W. B. Groups whose Orders are Powers of a Prime. Read Sept. 16, 1904 and Sept. 7, 1905. Transactions of the American Mathematical Society, vol. 7 , No. 1, pp. 61-68; Jan., 1906.

Ford, W. B. On the Analytic Extension of Functions Defined by Double Power Series. Read Feb. 24, 1906. Transactions of the American Mathematical Society, vol. 7, No. 2, pp. 260-274; Apr., 1906.

Fréchet, Maurice. Sur l'Ecart de deux Courbes et sur les Courbes limites. Read Sept. 7, 1905. Transactions of the American Mathematical Society, vol. 6, No. 4, pp. 435-449 ; Oct., 1905.

Glens, O. E. Determination of the Abstract Groups of Order $p^{2} q r ; p, q, r$ being Distinct Primes. Read Feb. 25, 1905. Transactions of the American Mathematical Society, vol. 7, No. 1, pp. 137-151 ; Jan., 1906.

HAskins, C. N. Note on the Differential Invariants of a Surface and of Space. Read Sept. 8, 1905. Transactions of the American Mathematical Society, vol. 7, No. 1, pp. 152-154; Jan., 1906.

Huntington, E. V. The Continuum as a Type of Order : An Exposition of the Modern Theory. With an Appendix on the Transfinite Numbers. Read Sept. 8, 1905. Annals of Mathematics, ser. 2, vol. 7, No. 1, pp. 15-43 ; Oct., 1905.

Hutchinson, J. I. On Certain Hyperabelian Functions which are Expressible by Theta Series. Read Sept. 7, 1905. Transactions of the American Mathematical Society, vol. 7, No. 1, pp. 21-25 ; Jan., 1906.

Kasner, Edward. The Problem of Partial Geodesic Representation. Read Aug. 31 and Oct. 31, 1903. Transactions of the American Mathematical Society, vol. 7, No. 2, pp. 200-206 ; Apr., 1906.

- A Geometric Property of the Trajectories of Dynamics. Read Sept. 7, 1905. Bulleten of the American Mathematical Society, vol. 12. No. 2, pp. 71-74; Nov., 1905.

KeLloGG, O. D. Unstetigkeiten bei den linearen Integralgleichungen mit Anwendung auf ein Problem von Riemann. Read Apr. 30, 1904. Mathematische Annalen, vol. 60, No. 3, pp. 424-433; May, 1905.

Keysen, C. J. Concerning Certain 4-Space Quintic Configurations of Point Ranges and Congruences, and their Sphere Analogues in Ordinary Space. Read Apr. 30, 1904. American Journal of Mathematics, vol. 27, No. 4, pp. 303-314; Oct., 1905. 
Lennes, N. J. Volumes and Areas. Read (Chicago) Dec. 30, 1904. Transactions of the American Mathematical Society, vol. 6, No. 4, pp. 486490 ; Oct., 1905.

Note on the Heine-Borel Theorem. Read (Chicago) December 29, 1905. Bulletin of the American Mathematical Society, vol. 12, No. 8, pp. 395-398; May, 1906.

Leonard, H. B. See Epsteen, Saul.

Leuschner, A. O. On the General Applicability of the Short Method of Determining Orbits from Three Observations. Read (San Francisco) February 25, 1905. Popular Astronomy, vol. 13, No. 6, pp. 296-305; June-July, 1905.

LOEwY, ALFRED. Ueber die vollständig reduciblen Gruppen, die zu einer Gruppe linearer homogener Substitutionen gehören. Read (Chicago) Apr. 22, 1905. Transactions of the American Mathematical Society, vol. 6, No. 4, pp. 504-533; Oct., 1905.

Lovetw, E. O. On a Problem Including that of Several Bodies and Admitting of an Additional Integral. Read Apr. 29, 1905. Transactions of the American Mathematical Society, vol. 6, No. 4, pp. 491-495 ; Oct., 1905.

Maclagan-Wedderburn, J. H. A Theorem on Finite Algebras. Read (Chicago) Apr. 22, 1905. Transactions of the American Mathematical Society, vol.6, No. 3, pp. 349-352 ; July, 1905.

Manning, W. A. On the Arithmetic Nature of the Coefficients in Groups of Finite Monomial Linear Substitutions. Read Sept. 7, 1905. Bulletin of the American Mathema'ical Society, vol. 12, No. 2, pp. 77-79 ; Nov., 1905.

- Groups in which a Large Number of Operators may Correspond to their Inverses. Read (San Francisco) Sept. 30, 1905. Transactions of the American Mathematical Society, vol. 7, No. 2, pp. 233-240; A pr., 1906.

Maschke, Heinrich. Differential Parameters of the First Order. Read (Chicago) April 22, 1905. Transactions of the American Mathematical Society, vol. 7, No. 1, pp. 69-80 ; Jan., 1906.

- The Kronecker-Gaussian Curvature of Hyperspace. Read (Chicago) Apr. 22, 1905. Transactions of the American Mathematical Society, vol. 7, No. 1, pp. 81-93; Jan., 1906.

Mason, Max. Beweis eines Lemmas der Variationsrechnung. Read Apr. 29, 1905. Mathematische Annalen, vol. 61, No. 3, pp. 450-452 ; Dec., 1905. See Buiss, G. A.

Miller, G. A. On the Possible Numbers of Operators of Order 2 in a Group of Order $2^{m}$. Read Sept. 7, 1905. Bulletin of the American Mathematical Society, vol. 12, No. 2, pp. 74-77; Nov., 1905.

- Groups Generated by Operators which Transform Each Other into their Powers. Read Oct. 28, 1905. Quarterly Journal of Pure and Applied Mathematics, vol. 37, No. 3, pp. 286-288 ; Feb., 1906.

Groups Containing only Three Operators which are Squares. Read (San Francisco) Sept. 30, 1905. Transactions of the American Mathematical Socrety, vol. 7, No. 1, pp. 94-98; Jan., 1906.

The Groups of Order $p^{m}$ which Contain Exactly $p$ Cyclic Subgroups of Order $p a$. Read (Chicago) Dec. 30, 1905. Transactions of the American Mathematical Society, vol. 7, No. 2, pp. 228-232; Apr., 1906. 
On the Invariant Subgroups of Prime Index. Read (San Francisco) Feb. 25, 1905. Transactions of the American Mathematical Society, vol. 6, No. 3, pp. 326-331; July, 1905.

The Groups Containing Thirteen Operators of Order Two. Read (San Francisco ) Feb. 24, 1906. Bulletin of the American Mathematical Society, vol. 12, No. 6, pp. 289-302 ; Mar., 1906.

- Groups in which all the Operators are Contained in a Series of Subgroups such that any 'Two have only Identity in Common. Read Apr. 28, 1906. Bulletin of the American Mathematical Society, vol. 12, No. 9, pp. 446449 ; June, 1906.

Moore, C. L. E. Classification of the Surfaces of Singularities of the Quadratic Spherical Complex. Read Dec. 29, 1903. American Journal of Mathematics, vol. 27, No. 3, pp. 248-279; July, 1905.

Morehead, J. C. Note on the Factors of Fermat's Numbers. Read (Chicago) Apr. 14, 1906. Bulletin of the American Mathematical Society, vol. 12, No. 9, pp. 449-451; June, 1906.

NeIKIRK, L. I. Groups of Order $p^{m}$ which contain Cyclic Subgroups of Order $p^{m-3}$. Read Apr. 25, 1903. Transactions of the American Mathematical Society, vol. 6, No. 3, pp. 316-325 ; July, 1905. Also Publications of the University of Pennsylvania, Series in Mathematics, No. 3, pp. $1-65 ; 1905$.

Nobla, C. A. Note on Loxodromes. Read (San Francisco) Sept. 30, 1905 Bulletin of the American Mathematical Society, vol. 12, No. 3, pp. 116-119; Dec., 1905.

Pierpont, James. On Multiple Integrals. Read Apr. 30, 1904 and Apr. 29, 1905. Transactions of the American Mathematical Society, vol. 6, No. 3, pp. 416-434 ; July, 1905.

- Inversion of Double Infinite Integrals. Read Apr. 29, 1905. The Author's Lectures on the Theory of Functions of Real Variables, vol. 1, chap. $15 ; 1905$.

- On Improper Multiple Integrals. Read Oct. 28, 1905. Transactions of the American Mathematical Society, vol. 7, No. 1, pp. 155-174; Jan., 1906.

PoINCARÉ, Henri. Sur les Lignes géodésiques des Surfaces convexes. Read Sept. 17, 1904. Transactions of the American Mathematical Society, vol. 6, No. 3, pp. 237-274; July, 1905.

Porter, M. B. Concerning Green's Theorem and the Cauchy-Riemann Differential Equations. Read Apr. 29, 1905. Annals of Mathematics, ser. 2, vol. 7, No. 1, pp. 1-2 ; Oct., 1905.

- Concerning Series of Analytic Functions. Read Apr. 29, 1905 . Annals of Mathematics, ser. 2, vol. 6, No. 4, pp. 190-192; July, 1905.

Quins, J. J. A Linkage for the Kinematic Description of a Cissoid. Read Dec. 29, 1905. American Mathematical Monthly, vol. 13, No. 3, p. 57 ; Mar., 1906.

Royce, Jostah. The Relation of the Principles of Logic to the Foundations of Geometry. Read A pr. 29, 1905. Transactions of the American Mathematical Society, vol. 6, No. 3, pp. 353-415 ; July, 1905.

Schottenfels, Ida M. A Set of Generators for Ternary Linear Groups. Read Sept. 17, 1904. Bulletin of the American Mathematical Society, vol. 12 , No. 2, pp. 63-68; Nov., 1905. 
Scott, Charlotte A. The Elementary Treatment of Conics by Means of the Regulus. Read Feb. 25, 1905. Bulletin of the American Mathematical Society, vol. 12, No. 1, pp. 1-7 ; Oct., 1905.

Sharpe, F. R. On the Stability of the Motion of a Viscous Liquid. Read Feb. 25, 1905. Transactions of the American Mathematical Societ,, vol. 6, No. 4, pp. 496-503; Oct., 1905.

Shaw, J. B. Significance of the Term Hypercomplex Number. Read (Chicago) Apr. 14, 1906. Bulletin of the American Mathematical Society, vol. 12 , No. 10 , pp. $485-492$; July, 1906.

SisAM, C. H. On the Determination of the Properties of the Nodal Curve of a Unicursal Ruled Surface. Read Sept. 7, 1905. American Journal of Mathematics, vol. 28, No. 1, pp. 43-46 ; Jan., 1906.

Smith, A. W. The Symbolic Treatment of Differential Geometry. Read Feb. 25, 1905. Transactions of the American Mathematical Society, vol. 7, No. 1, pp. 33-60; Jan., 1906.

Smrth, Burke. Certain Surfaces Admitting of Continuous Deformation with Preservation of Conjugate Lines. Read (Chicago) Dec. 30, 1904. Bulletin of the American Mathematical Society, vol. 12, No. 4, pp. 164-171; Jan., 1906.

- Determination of Associated Surfaces. Read Oct. 28, 1905. Bulletin of the American Mathematical Society, vol. 12, No. 7, pp. 342-346 ; Apr., 1906.

SNYder, VirgiL. Surfaces Generated by Conics Cutting a Twisted Quartic Curve and an Axis in the Plane of the Conic. Read Feb. 24, 1906. Bulletin of the American Mathematical Society, vol. 12, No. 8, pp. 383-387; May, 1906.

Stäckel, Paul. Die kinematische Erzeugung von Minimalflächen. Read Feb. 24, 1906. Transactions of the American Mathematical Society, vol. 7, No. 2, pp. 293-313; Apr., 1906.

Stephens, R. P. On the Pentadeltoid. Read Dec. 30, 1905. Transactions of the American Mathematical Society, vol. 7, No. 2, pp. 207-227; Apr., 1906.

Stromquist, C. E. On Geometries in which Circles are the Shortest Lines. Read Feb. 28, 1903. Transactions of the American Mathematical Society, vol. 7, No. 2, pp. 175--183; Apr., 1906.

Townswnd, E. J. Arzelà's Condition for the Continuity of a Function Defined by a Series of Continuous Functions. Read Sept. 8, 1905. Bulletin of the American Mathematical Society, vol. 12, No. 1, pp. 7--21 ; Oct., 1905.

Veblen, Oswald. The Square Root and the Relations of Order. Read (Chicago) Apr. 22, 1905. Transactions of the American Mathematical Society, vol. 7, No. 2, pp. 197-199 ; Apr., 1906.

- Remark on a Measure of Categoricalness. Read Feb. 24, 1906. Bulletin of the American Mathematical Society, vol. 12, No. 6, pp. 302-305; Mar., 1906.

Veblen, Oswald and Bussey, W. H. Finite Projective Geometries. Read (Chicago) Apr. 22, 1905. Transactions of the American Mathematical Society, vol. 7, No. 2, pp. 241-259; Apr., 1906.

White, H. S. Rational Plane Curves Related to Riemann Transformations. Read Sept. 8, 1905. Bulletin of the American Mathematical Society, vol.12, No. 4, pp. 157-158; Jan., 1906. 
Wilson, E. B. Sur le Groupe qui laisse invariante l'Aire gauche. Read Apr. 29, 1905. Nouvelles Annales de Mathématiques, ser. 4, vol. 5, pp. 163-170; Apr., 1905.

- Note on Integrating Factors. Read Feb. 24, 1906. Annals of Mathematics, ser. 2, vol. 7, No. 3, pp. 155-160; Apr., 1906.

Wright, J. E. On Differential Invariants. Read Apr. 29, $1905 . \quad$ Transactions of the American Mathematical Society, vol. 6, No. 3, pp. 286-315; July, 1905.

- The Differential Invariants of Space. Read Apr. 29, 1905. American Journal of Mathematics, vol. 27, No. 4, pp. 323-342; Oct., 1905.

- An Application of the Theory of Differential Invariants to Triply Orthogonal Systems of Surfaces. Read Dec. 29, 1905. Bulletin of the American Mathematical Society, vol. 12, No. 8, pp. 379-382; May, 1906. 